\title{
The Phenomenon of Political Myth in the Social Space of Modernity
}

\author{
Alia Hairullayevna Ramazanova ${ }^{1}$, Zhamilya Amangeldievna Amirkulova ${ }^{1}$, Akmaral Karzhauovna Baidlayeva ${ }^{1}$, \\ Zhadyra Nurganatovna Kazieva $^{1} \&$ Kenzhegul Biyazdykova ${ }^{1}$ \\ Faculty of Philosophy and Political Science, Al-Farabi Kazakh National University, Republic of Kazakhstan \\ Correspondence: Alia Hairullayevna Ramazanova, al-Farabi Ave, 71, Almaty, 050038, Republic of Kazakhstan.
}

Received: December 22, 2014 Accepted: March 26, 2015 Online Published: May 22, 2015

doi:10.5539/ass.v11n14p277 URL: http://dx.doi.org/10.5539/ass.v11n14p277

\begin{abstract}
The paper considers a theoretical analysis of the political myth phenomenon, which on the one hand is evident as socially and psychologically conditioned phenomenon; on the other hand, political myth can provoke certain social processes. The paper covers the peculiarities of the political myth functioning in the social space of modern time.
\end{abstract}

Keywords: political myth, power, national mythology, political language, archetype, mythological consciousness

\section{Introduction}

Currently the political mythology has become one of the hottest topical research issues. Exhibition of 'mythical' in politics is one of the main factors for the 'revival' of interest in the myth in the modern society. Myth today turns into the 'favoured sphere' for different political schemes, slogans, ideology. On this basis, the author considers it expedient to review functioning of the myth in politics.

As an object of intellectual reflection, the political myth has attracted great attention of researchers of diverse area of humanities knowledge. It was caused by the 'most available obviousness', 'demonstration' of modern myths precisely in the area of political action. According to Kazakhstani researcher Bekezhan O. (Bekezhanov, 1998), it is very strong politicization of all spheres of human activity that caused actualization of the political myth.

The political myth case study dates back to the first half of the last century and is related to the understanding of the specific features of political leverage in mass (information) society. Georges Eugène Sorel, Serge Moscovici, Ernst Cassirer, Mircea Eliade and others are among the authors who most thoroughly studied the phenomenon. It is their undeniable merit is that they considered the political myth as 'actualization of the latent, temporarily hidden strata of culture', and not only as the result of deliberately false lie, that was introduced in the society.

Georges Eugène Sorel was among the first researchers in political environment who gave a sharp awareness of the role of myths. Thus, G.Sorel for the first time spoke about the 'myth', having in mind the summation of efforts that contribute revolutionary proportions to ideology. According to Sorel, myths must 'reflect tendencies, instincts, expectations' of people or party, that allows clearly illustrate all these fears and aspirations in the form of 'integrity'. Yet it doesn't matter at all that myths, in particular, look 'surreal' and 'considerably deviate from the reality'; as the point is just to influence the human imagination' (Hyubner, 1996, p. 340).

According to Sorel, myth is a symbolic transfer of rationality into the language of the masses, which authorizes and activates their total mobilization. Social structure and the dependant ideological concepts (in particular, legal matters as well) are based upon the worldview and understanding of the social and political, which is fundamentally irreducible to a purely rational structures. The social structure is the result of full range of images (myth) and the will of the people (mobilization). In this context, myth is antithesis to the absolutely intellectual rationalism.

The theory of political myth (especially finding out the myth effect on the social phenomena) is also associated with Serge Moscovici. Along with the ideas of Le Bon Gustave, he develops a theory of social images, which to some extent was similar to Émile Durkheim's theory of collective representations. By social image he meant commonplace sense, formed mainly by nonrational affects, to a certain extent by ideological views and to a 
small extent by scientific knowledge. In the area of social image we are faced with a complex intertwining of rational and irrational, scientific knowledge and 'common sense'.

Developing Le Bon's ideas, Moscovici advances his own set of ideas on the role of myths in modern history (Moskovichi, 1998, pp. 126-127). According to him, mass is not just crowd of people, but aggregate with psychic community. It operates unconsciously (the unconscious has a collective nature). Masses bear on the leader's support, being obeyed by the authority, not by reason. In his turn, leader bears on some mythic image. Crowds are operated by propagandistic hypnogenesis. In politics the regularities of controlling masses of people require advancing a supreme idea and its introduction into consciousness of the masses. In response to indoctrination, the idea becomes a collective image (deeper - into the political myth) and collective actions.

According to Ernst Cassirer, the political myth is a creative process that occurs in critical moments of society. In his opinion, during the period of political stability there is no need in myth-making. In particular, he believed that people who are in balance of mind shall not be in eschatological mood and won't be willing to restrict their personal freedom by those who are staying in power, so his conscience will not possess mythological component While a person acts within the common, living environment, he hardly ever goes by considerations of a mythological order and does not seek refuge and does not escape reality in the mythical ideas and rituals. When a person enters into the sphere of politics with its complex rituals, different from his common environment, his everyday consciousness is no longer able to help him navigate the surrounding spiritual environment, and he is forced to seek the assistance of political mythology, which explains to him the meaning of political action as a specific ceremony (Kassirer, 1993, p. 154).

In the $70 \mathrm{~s},-80 \mathrm{~s}$ of the XX century a wide range of studies on the social mythology is published within the context of criticism of ideology (Gurevich P. S., Makarov M. G., Lifshits M. A., Shestakov V. P. and others). Of special note is Gurevich P. S. with his 'Social Mythology', where he analyzes the approaches to the understanding of socio-political mythology from the standpoint of 'criticism of bourgeois ideology and revisionism'.

\section{Method}

Of special note is that some researchers of the modern political mythology chose not to further study the subject as a matter of moral compulsion. The myth of Nazi Germany, the mythology of the nation, the myths of the Soviet era became a trigger for declaring everything related to the collective unconscious, irrational moments of social control as dangerous and immoral. Many researchers preferred contrivances to work out methods of controversy to political mythology and to myths management, as 'in the socio-political sphere myth creates the illusion that people and power are united, as according to the myth they are consolidated by shared objectives and move towards them; critical reflection is excluded in the myth, thus providing strength and firmness of ideology and political structures; myth serves the spiritual and psychological support to the political regime upon which the possibility of manipulating the consciousness of the masses is possible; at a certain stage of history, myth acts as the meaning of life for a social group, society or ethnic group, it can play the role of the meaning of life for an individual who is the part of this community; myth galvanizes masses into action for the sake of imposed goals; myth creates a reassuring picture of the world, reconciling a man and masses with 'temporary difficulties' and disasters, and myth is a shelter from irrational fears, invisible social dangers and enemies (Pivoev, 1993, pp. 37-43).

In whole, in philosophical, politological and sociological practice, the attitude towards the socio-political myths is mainly negative. First of all, this was due to a number of reasons: the willingness to see the political myth as something external to the real life, which has no positive esthetics; negative attitude towards the socio-political mythology was caused by manipulative practices of political groups and parties that use the myth for 'seizure' of the audience and long-term retention in the right direction; according to Avtonomova N.S. modern myth '... in its social role cannot be in sympathy with humanistic ideas. The fascist myth alone is well enough to maintain antipathy to manifestations of mythological consciousness and expose them to humanistic denial in the style of negative dialectics' (Avtonomova, 1990, p. 55).

Most researchers so deeply associate the political myth with the ideological sabotage that they concentrate only on the criticism of 'totalitarian mythology' of Stalinism and the German National Socialism. Moreover this criticism of 'totalitarian mythology' was identified with the 'demythologization' of science and mass consciousness and the breakthrough to the objective political knowledge, resulting in narrowing the boundaries of the socio-political mythology ideas. According to the methodological definition of Losev A.F. the "theory of myth, which does not capture the culture up to its social roots, is a very bad theory of myth. Only very poor 
idealists divorce myth from the thick of the historical process and preach liberal dualism: real life is on its own, and the myth is on its own' (Losev, 1994, pp. 22-23).

Myth is fiction, not conscious but unconscious one. Therefore 'it is necessary to disclose not the contents of purposeful fabrications, but rather the importance of the hidden image (not of the myth) - classify objects and motifs of mythological thought. In politics it will respectively be unconscious goals, exalting myth-making or inspirational images that represent certain values. These are the 'disguised phenomena' that politicians should 'unspell'. However it should be noted that any attempt to introduce these unspelled phenomena into policy is destined to fail. Only through a new 'enchanting' in a new, transformed form, they can be assimilated in the political practice... The analysis methodology must observe the 'golden mean', where the analysis is not entangled in countless details of specific myths, and at the same time does not reduce the mythology to some simple reasons or object in the real world' (Kassirer, 1998, pp. 13-14).

Thus it is incorrect to consider any phenomenon (including socio-political myth) only unilaterally. According to E.Cassirer 'myth has, so to say, a double face. On the one hand, it shows us the conceptual structure, on the other - the perceptual one. Myth does not mean accumulation of disordered and incoherent ideas; it depends on the specific shape of perception' (Kassirer, 1998, p. 386).

As noted earlier, the role of myth goes beyond the introduction of the given political ideologeme into the public consciousness. In proof of this statement let us consider and disclose the essence of the socio-political myth.

The political myth as well as the archaic myth is characterized by a specific set of components: a picture of the world as a confabulated concept of social Truth (the basis of fairness), the point in the course of time, associated with the roots of national history and culture, the moment of their supreme worshiping or severe injury (the analog of initiative emotional stress in the mystic ritual - chosen glory or trauma), a vision of the future (interpreted as getting round to ancestry of the 'Golden Age') and deep opposition 'we - they' (the analog of the mythical opposition between Good and Evil).

If the challenge for the archaic myth was that any social action reproduced cosmogonic model of the world (i.e. restored the worldview), then the cultural task of the political myth is to restore the social picture of the world that was destroyed during the social cataclysm.

Another aspect of the political myth is in structuralization of reality in the situation of total crisis, i.e. in the situation where it's not possible to restore the world view and build a holistic picture. It is divided into the fragments, which are connected with the mythological ties. And only later on mythological constructions 'gather' rational ideas, concepts, legal and political beliefs.

The political myths are not eternal, they are often ruined under the influence of the social earthquake, but they are immediately replaced by the new ones, because myths help people to facilitate the perception of reality. Short life can be noted as a characteristic feature of the political myths. As a rule, the political myths are the reflection of a particular historical moment. With the change of specific conditions, myths are also replaced. According to the psychosocial approach of Moiseev I. V. 'the birth of the political myth happens when the social injuries flow into the psychological injuries' (Moiseev, 1994, p. 5). Therefore, most theorists of full range of various directions understand such periods in the history by means of analyzing the role and place of the myths in the crisis situations. No wonder that A. Jaurès, the French historian and politician of the first half of the XIX century, while exploring the events of the French Revolution, noted that it seemed as if people dealt not with real but some imaginary society in which everything seemed simple, reasonable and uniform. The imagination of the crowd turned away from what actually happened. 'The spirit of the crowd soared in some perfect state, created by the imagination of writers' (Zhores, 1983, p. 340). Whereas Le Bon noted that the crowd or mass does not possess a critical consciousness and that it does not think the categories but thinks the images, which might be far from the reality (Lebon, 1995, p. 290). Thus, reliance on sensual reflection is another feature of the political myths. Modern myths often do not appear spontaneously, but are created artificially, consciously and purposefully. Myths are based on collective aspirations and hopes that are conscious and cultivated by politicians As already mentioned, the mass has no logical law. Mass perceives only what in some degree is related to common requests, e.g. justice in the abstract, which cannot, for objective reasons, be fully implemented in the reality. Therefore masses perceive some provisions, stereotypes, myths, only based on faith. Recognition of something true without prior actual or logical check, based only on the internal, subjective immutable beliefs, becomes the 'trap' for the human brain. Justification takes place on the basis of feelings, emotions, which contradicts logical explanation. This becomes a ground where myth-making occurs.

The political myth doesn't spring out of nowhere, otherwise it can't enter the competitive field of politics. According to E. Cassirer, despite immersion in the myth, a civilized man, like an ancient man, still cannot 
completely abandon the requirement of rationality. For his faith he seeks some reasonable grounds. The respective theoretical formulation of beliefs can be rather difficult, though leads to the affect, similar to beliefs of primitive people (Kassirer, 1993, p. 112). In our opinion, this is one of the main differences between the political myth and the myth itself. The political myth is and cannot but be rational.

When a politician in power lacks authority, he actively claims to obtain the Creator's power. And for this purpose he turns to the mythical topics, as he finds in them condition, argument of legitimation of his power and clearly stated, chosen policy. When myth becomes the property of collective representations, it forms a certain view of life, psychological and ideological attitude, that possess the endurance of superstition. Myth creates fictional cause and effect relationship between social objects, generates false objects (heroic images of ordinary politicians), creates the legends of the glorious past, replaces social reality by fiction (sometimes uplifting, but often scathing), introducing it as a true outline of political relations.

\section{Results}

Why is myth so attractive to a politician? Firstly, because of the scope. The scope is so huge that provides an opportunity to create and recreate the social space. Moreover, myths assume enormous degree of subordination and dependence. The global nature of such relationship acts as one of the premises for the existence of the myth.

Secondly, in this setting a politician gets a chance to act as the 'Creator' and a creative personality, as the director of the epic political theater where plays range from tragedy to farce and are all based on some mythical stories. It is incredibly tempting to place himself in a key position and with a huge number of assisting day players in the show, represent a play, for example, about the creation of the 'new world' on the ruins of the 'old' one; or 'absolution' of the country from the 'sins'; or 'consecration of the favorites'.

Third, with such power a politician is able to establish control over the social time, completely eliminating the entrusted territory and people from the sphere of action of the mythical time. A person with no landmarks in the 'past - present - future' system, morphs into a mere blind, weak-willed toy in the hands of the people in power. And the society, forcibly taken out of the context of the historical development of mankind, is fatally on the rocks.

Fourthly, on the ground of the precedent of 'the creation myth' the leader, set in such authority, has the possibility to represent the Law single-handedly and to be the impersonation of Justice and Order in principle.

Some confabulated idea of a political nature is the concept of the political myth as a system. Throughout the course of history of mankind two following ideas are most commonly ingrained in the minds, with some metamorphoses: the idea of the possibility of implementing the ideal model of the state structure in the setting of the ontic reality, and the coupled idea of the possibility of the existence of the perfect person, who is able to turn this model into reality.

According to Kaskabassov, it seems probable that the ideas and stories emerged in the ancient times and then were repeatedly updated and revived in the periods of the history with difficult or crisis situations. (It is well-known that from olden times almost all nations had their myths about the 'golden age'. The Kazakhs also have similar myths. They tell about the wonderful time when everything in the world was so harmonious that 'larks could quietly make nests on the sheep backs' (koi ustinde boztorgai zhumytkalagan). In the Kazakh mythology those are the stories about the so-called Zheruik and sometimes about Zhideli Baisyn where people would have the life of Reilly and live a free-wheeling existence) (Kasкabasov, 1992, p. 266).

One of the political myth peculiarities is its incompleteness. In fact, it is absolutely impossible to find a completely formatted political myth in the political mythology. Since the political myth is never being completed in full, in the end, it evolves into the unification and degeneracy stage, and eventually the political myth is no longer a mobilizing force.

The structure of the political myth consists of a system of values, generated by the conceptual idea. Its elements are definite ideas that represent the system of values. The peculiarity of the political myth structure is that it is a two-level structure, as the political myth is implemented at two levels of political consciousness - ordinary and specialized. At each level of consciousness the formation and functioning of political myth is provided by two directionally different and at the same time interdependent structural relationships. So, on the ordinary level of the political consciousness the faith is such structure-forming relationship; the faith is fastened in mind, so a man places any myth created either by his own or other people's imagination in the ontic reality. Thus, due to the faith predominance in this consciousness, for the consciousness of his subject, myth becomes a part of the ontic reality. At a specialized level of the political consciousness, the goal orientation is its structure-forming relationship that ensures the myth existence in the mind; the essence of the goal orientation is to manage the different 
consciousness by changing this consciousness, according to the desired model. The relationship of the structure-forming relations that determine the existence of the political myth at the appropriate levels of consciousness, is expressed in implementation of goal orientation, determining the political myth vitality at a specialized level of political consciousness, as a rule is impossible without activating the faith, providing the existence of the myth as such on the everyday level of consciousness.

Among the significant publications of recent years on the political myth problem, we should note two monographs, published in the year 2003 under the same name 'The Political Mythology'. The author of the first monograph is Tsuladze A., the famous Russian theorist and publicist, the second researcher is Kolyev A. N.

According to Tsuladze A., the political myth is 'a myth used to implement political objectives: struggle for power, implementation of the political rule' (Tsuladze, 2003, p. 56).

Kolyev A.N. provides his definition of this phenomenon. According to him, "the political myth is an archetypical structure, projected in the sphere of self-organization of society or people. The link with the archetype means the involuntariness of myth-making and its interaction with the objectively existing system of thought, laid in the archetype. The political myth requires an answer to a specific question - eternal (as in religion), or momentary, transient, but still associated with the unconscious desire of masses. This is how myth differs from pseudo-myth, where empathy is only simulated by means of some stimulus. (For example, some private or group interest claims to be the 'national idea' element). When the stimulus disappears, empathy disappears as well. However, the specificity of the political myth brings it together with the embellished allegory of the particular interest' (Kolev, 2003, p. 75).

Thus, both researchers describe a myth not as an archaic society attribute, but as a phenomenon of the contemporary mass consciousness.

From our point of view the study of Kolyev A.N. is of interest. With all the diversity of judgments about the nature of the political mythology, a researcher must overcome widespread negative attitude towards the political myth that dominates in the contemporary scientific literature, political journalism and rhetoric. In the opinion of the author, moving away from negativism in regard to the political mythology will restore the dialectical vision of social processes, expressed not only in the general laws of evolution, but also in the duality of the political activities, due to the difference in the perception of mass and individuum. According to Kolyev A. N., the political myth with archaic images, is capable of carrying quite positive properties. First of all this is a symbolic, plot layout of politics in the absence or insufficiency of rational motives. Choosing symbols, we choose the path of society, even if it is not quite clear to us.

The researcher focuses on the fact that myth is a necessary component and in many cases the constructive component of political consciousness. The author particularly stuck at the national mythology as one of the spiritual and creative powers, which could help to overcome the outlook crisis in the country and the implementation of a new positive future of the country. In particular, he writes, 'The return of life to science necessarily requires the return of myth in politics. And, more precisely, it is creation of the Big National myth that will inspire high civic consciousness, love of the country, love of the native history, ancestors and descendants. Such myth would restore ruined link of times, the link of the present with the past and the future, will get back a sensible understanding of social hierarchies and point the place and the area of efforts of scientific work.

Presenting the Big National myth as the Big cultural style for science, means the necessity to get rid of the concept of politics as a competition of egoism and greediness. As a result, the political mythology could become not only a scientific concept, but also a source of political doctrine of the revival of the state and elimination of the shameful mercantile system in the life of the modern society' (Gachev, 1994, p. 75).

The myths, based on the national feelings, generated by the same ontological concepts as the mythical understanding of clanship, seem to be fruitful and 'everlasting'. Sharp differences of material and ideal, internal and external also disappear here. The environment in which the nation lives and materializes (landscapes, monuments, places of worship, national clothes, etc.), traditions and customs are part of the inner nature of every person who belongs to this nation. It is not easy to destroy the national myth, because a person and Motherland are considered as an aggregate. Any attack of a 'stranger' on such kind of myth can result in nation's consolidation around the myth.

It is the national myths that make the 'soul of people', as '... nation is understood through the prism of the myth, and determined through archetypal understanding of the history. However, the one who defines nation in such a way mythologises the space belonging to it (...). Everywhere - in the mountains, in the valleys and plains, in the 
river bends and in the cities - there are 'witnesses' of the past, which, as stated above, are perceived as the ideal and material, and thus the substantial part of the present' (Hyubner, 1996, p. 327).

Being formed in the period of formation of the nation, the national myths accompany it throughout the course of the history. The national identity is based on myths and is inseparable from them. Historical events become significant for future generations, when they are included in the structure of the national myth. In this case, the history of the nation is a myth created by the nation about itself. Historical events serve only as the construction material for the myth of the nation.

The national idea is the main component of the national myth. The researcher Turyszhanova R. K. notes that today 'we need an idea of the Motherland, the most important democratic value, the meaning and significance of which no one would dispute. The history of world civilization knows many examples of crisis management and crucible under the banner of national ideas: 'The Motherland is in danger!', 'Welfare society' and others. Would the Soviet Union be able to resist the enemy, and then defeat him, if they didn't name the war as the Great Patriotic War, thus contributing to the unprecedented rise of patriotism and awakening of the best national feelings in the people? And lack of the national idea in Iraq has led to the inevitable and crushing collapse of Saddam Hussein's regime' (Turyszhanova, 2003, p. 118).

People invest in the nation's myth-making the content of his unconsciousness - the experience of ancestors embodied in the symbols, the elite invest a conceptual vision of the whole mythological design and game images - political advertising and national ritual. Consistently reproducible mythology becomes the basis of the national identity.

Polosin V. S. says 'Mythology of the nation is an allegorical image of its moral ideal, its 'blood' and 'soil', it is an allegorical autobiography of the nation' (Polosin, 1999, p. 94). This image reflects the hierarchy of social consciousness structures, and historical pantheon of national heroes, and the ideal of organization of the living space of the nation, and the social hierarchy that is organic to the national history.

According to Polosin the structure of the national mythology is as follows:

1) The archetype of the Great Motherland, symbolizing the origin and the purpose of people as a macro-family;

2) The history, idealized as the frame plot of the universe, and the space, idealized as the geographic center of the Universe;

3) A system of symbols that by means of archetypal key-benchmark (the image of Motherland) will decode the mythical collective experience ('the must') and relate to it 'the desirable';

4) Archetype of superman-Arch father (ancestor of the national elite, the Hero patron), embodies the image of the Hero-superman, based on the national elite and folk archetypes (Polosin, 1999, p. 94).

Cumulative social experience ('the must') is transformed into the idea of the absolute, which, in turn, is associated with the transcendent 'the real', inhabited by the earlier generations, led by Arch father of the nation. In this space of the archaic myth one can see the spiritual and moral completeness of the folk tradition, understood as the expression of the Absolute, divine Absolute-father. Return from the mythological sphere gives the spiritual image of the Great Mother - the hypostasis of the Absolute, which in its earth existence is associated with the concept of the Fatherland (Otan, Zher-Ana), in which the nation feels itself the subject of history. This image covers all national mythology and reproduces it through the national elite, which protects the national leader-hero. Thus, the 'children' of the Absolute are the earthly Homeland, the national elite and the Hero - the voicer of the sameness of the nation, 'the desired' by the canons of 'the must'.

Polosin V.S. notes that 'the national mythology is the subconsciousness of people, 'the well of time' of a big Family, art, mythopoetic allegory about her actual experience, the archetypes of which are expressed in symbolic images. The basis of the national identity is the education of natural nationalism - feeling of the big family, united Motherland-Mother. Family members are 'their', others are 'strangers' and 'remote'. In order 'strangers' could become 'friends of the family', family itself must be available first' (Polosin, 1999, p.98).

The political components of the myth of the nation are the following defensive and conservative ideas: keep the territory, restore the demographic potential, preserve the culture, and regain position in the world civilization.

Kolyev assumes that conceptualized political myth can become one of the technologies of the effective society management, of securing its consolidation, and resistance to destruction of philosophical foundations of the state existence. Demonstration of the national archetype, deep mythological notions of Good and Evil, Justice and Truth are salutary for the country, living in conditions of socio-economic and cultural crisis (Kolev, 2003, p. 377). 
'Those who are trying logically, solely rationally and mechanically 'to calculate' the project of the rebirth of the state, mostly hit the wall' (Kolev, 2003, p. 377). According to Kolyev A. N., you must create the national myth, which must include a wide layer of cultural tradition, with all the history and the mythological symbolic world, and it might actually fill the deserted 'middle' space of people's way of thinking. In this case not the Truth but the Victory becomes the dominant idea; not humanity but the nation becomes the main value (Kolev, 2003).

The 'corporeal' project of the myth gets close to the miracle. By a miracle people often understand 'what cannot be'. But this is interpretation of a non-mythical observer. A subject, taken up with myth, does not see anything supernatural in the miracle. For him miracle is natural, but unusual for its beauty, specific harmony, with which it fits into the reality. Anticipation and yearning for a miracle is anticipation to reveal a natural link of things, which until now has been hidden. Losev A. F. writes that miracle is associated with personality, history and symbol and is a synthesis of a certain detachment and phenomenon, a symbol and self-consciousness of a personality - the source and origin of this consciousness.

Miracle is not a violation of the laws of nature, but their deep understanding, identifying the authenticity. In social practice, political magic, indeed, reveals certain relationships that become a productive force (for example, the enthusiasm of the first Soviet five-year industrial plans.

In the 'Dialectics of Myth' Losev writes: 'The miracle basically possesses the nature of notification, demonstration, annunciation, evidence, wonderful sign, manifestation, a kind of prophecy, disclosure, but not the existence of the facts, not the occurrence of the events. This is the modification of the meaning of the facts and events, but not the facts and events themselves. This is a certain method of interpretation of historical events, and not finding some new events as such' (Losev, 2001, p. 147).

Of course, not every myth-making leads to salvation, to miracle. It is well known that our mind can generate not only miracle, but monsters as well. But here it is not a case of a superstition, but of a quite conscious acceptance of myth. Mythology creates a specific language of understanding, language of unity around not mastered, but entailing supreme values. Here it is important not to confuse the dream, enlightening the mind, with drug induced sleep. Focusing on myth, we participate in the actual process of struggle between Good and Evil, which takes place in a mythological world, making indelible impact on the history of Earth.

Each nation has its archetypical features, because archetypes were formed at the beginning of its history. After being formed, they accompany people throughout the complete historical path. Therefore, so that to become a mythological character, the politician needs not just to create some structure, but to fit in the 'eternal' national myth, because it is the national myth that makes the 'soul of the nation'. If the myth has the 'corporality' and if it has the 'soul of the nation', then it also has the 'body of the nation'. According to Losev A. F., 'the body is not mere fiction, not a random phenomenon, not just an illusion, not trivial issues. It is always a manifestation of the soul, its footprint. To some extent, it is the soul itself '(Losev, 1994, p. 75).

The myth and the man proximity is regularly used in politics. 'Not any social or political technology, activity in the sphere of management or any marketing strategy can be effective without considering the archetypal layer in the human mind' (Ryazanova, 2005, p. 256). Ryazanova S. V. assumes that each mythological system has a perfect image of the ruler or tsar, who is the custodian of justice and the guarantor of social responsibilities observance. Or this is the image of the deity with anthropomorphic features. Ryazanova S. V. says that these images are projected onto the area of socio-political relations in all known traditional cultures. Since Kazakhstan is among traditional societies, it can fully be related to it.

'Archetypical base in the perception of power and power holder not the least bit transforms in the process of specious modernization, typical for most traditional societies. Outerly sacral character as some paradigm can be changed that does not affect the essence of the dominant traditional governance model' (Bart, 1989, p. 258). Hence, it means that we choose the leader who meets the basic archetypical image of the ruler. An acknowledged leader in politics is the one who is able to represent the archetypical image of 'father'.

A politician, being the subject of myth-making, at the same time is an object of other myth-making projects. Beeing the leader of his supporters, at the same time he becomes a function of expectations and instinctive expectancies of the masses. Appeal to the spiritual and moral measurement of the political process allows revealing the mutual interaction of mass phenomena and behavior of political leaders, who embody prototypical images of the mythical heroes. On the one hand, the political character reflects the collective aspirations of the masses, that has lost the sense of integrity of 'the world picture', and the other he becomes a source of ideological standards, re-establishing 'world picture' in the new conditions. For a politician the myth becomes an integral part of his role function and the tool of political competition. 


\section{Discussion}

Myth-making is a method to restore the reality not only for oneself but also for others. An attempt to build a myth, even if it is an instinctive attempt, at the same time is an attempt to impose your outlook to other people. Perhaps it is most clearly seen in politics. A person or a group who are attempting to create the political myth or to ride the existing myth, try to thrust not only a certain vision of the picture of the social space and the state system, but also his outlook on nature and society. That is why we should expect the dominance of a certain mythological system, which will be approved after the country gets out of the ideological crisis.

But society is not always ready to trustfully accept the myth. Confidence arises only when the myth reflects the collective will, and aggravation in the society results in politicization of the mass consciousness. Confidence also arises at certain specific features of the national-cultural mentality and statehood.

Within this framework, the political myth is the result of human faith in the fact that any power must reveal itself, act as active force, which can be used, if to believe in it. That is why myth can be associated with any form of social power or social claim to power. Myth is always used for justifying and for some special privileges, duties, social inequalities.

R. Barthes wrote, 'Myth is a word, a sentence, and it may be anything that is worthy of a story. For providing the definition of the myth not the object of the message itself, but the way it is reported, is important' (Bart,1989, p.111). Myth is a word, chosen by history. Both in ancient times and nowadays mythology can find its grounds only in history - myth can not arise from the 'nature of things'. Myth is also a message. It represents one of the ways of denotation. The message does not necessarily have to be expressed verbally, it can be a letter, image, photograph, cinematograph, journalistic story, and much more can be 'tangible media of mythical messages', which represent only a starting material for the myth creation. According to Barthes, the main objective of the myth is 'to grant historically conditioned intentions to the status of natural intentions, and bring historically transient facts to the level of eternal ones' (Bart, 1989, p. 111). The outside world provides some historical reality to the myth, while the myth assigns the reality a surface gloss of naturalness. It's in the myth that objects 'lose' the memory of their origin. After special mythological adaptation the world appears as a harmonic picture of eternal essence. As a result, objects are deprived of the human meaning and begin to mean only that the person is uninvolved in them. Thus, the purpose of the myth is in the devastation of reality.

Barthes defines the modern myths as an assembly of connotative means, forming a latent ideological level of discourse ('the area common to all connotative means, is a sphere of ideology' - Barthes). The purpose of the myth is twofold: on the one hand, it aims to deform the reality in order to create such an image of reality, which would coincide with the value expectations of the mythological consciousness bearers; on the other hand, the myth is extremely concerned about hiding its ideology, because any ideology wants to be perceived not as one of the possible world viewpoints, but as the only allowed image, that is, as something 'natural, normal state of things'. Myth does not hide its connotative meanings; it 'naturalizes' them and therefore it's no coincidence that it freeloads on ideologically neutral signs of the natural language.

According to Barthes, the essence of the myth is limited to a single goal - 'the abduction of the language' (Bart, 1989, p. 115), a distortion of the meaning and form. In this case Barthes perceives the politics not 'as the active participation of citizens in public life', but rather as an assembly of human relations that form a real social structure, the ability to create peace.

Being a representative of the structuralist movement, he treats political myth as a secondary semiological structure built over ordinary language. It is a specific meta-language, which builds its own language system on the basis of the language system. Subsequently the political myth is perceived as a system of facts, and according to Roland Barthes is a semiological structure.

What is the socio-political myth-making 'technique' that is at its origin? Many researchers note that social myth-making includes both moments of individual creativity and reflection of mass political consciousness. Historical and contemporary socio-political experience allows to emphasize the following common methods of the political myth-making:

Firstly, it is an appeal to the historical tradition, its integration into the structure of political practice and political knowledge as the strategies or tactic. So, depending on the political orientation, various parties and groups present their options of going back to a particular period of the past. Mythologizing of the past and the transfer of ideas about the past into the future, lead to the fact that the description of the purpose is replaced by a description of means to achieve it. 
The transfer in time in mass mythological consciousness can be replaced by the transfer in space. In modern political mythology the idea of transfer in space is presented by a variety of options for the transfer of economic and political models of development (so-called model of 'Japanese miracle', 'American miracle' etc).

Secondly, it is scientific popularization of political information. For example, the party programme myth-making and media activities. In his work 'Manipulation of consciousness' Kara-Murza S.G. writes, 'It's an expert in the modern politics in the West that became one of the important figures and convinces the society in a salutary influence of a decision. Often in this case there is a conflict of interests of authorities, backed by the financial and industrial magnates. If they do not result in collusive agreement, then philistine and deputies are entertained by the 'academic' debate show of the opposing groups of experts.

... At these shows the democracy is nowhere near, as the opinion and concerns of simple people are brushed aside as being ignorant and irrational. The unenlightened representatives of the elite are more politely suggested to study the issue first before starting to criticize. L. Wiener in his book 'The Autonomous Technology' notes that 'this advice is a sort of power legitimation by means of expert's knowledge, and according to my experience, contains not only an invitation to expand the knowledge but rather negotiations for capitulation' (Kara-Murza, 2002, p. 212).

By nominating expert scientists as a special layer of propagandists, who manipulate public opinion, the USA further than other countries moved from the democracy to such mechanism, which has been called 'the decision-making state'. Thus by imitating the science impartiality (freedom from ethical values), politicians replace the problem of choice, which applies to all citizens, by the problem of decision-making, which is the internal affair of politicians and experts '(Kara-Murza, 2002, p. 212).

Thirdly, it is the personification of the idea, its transformation into the image of a political leader or some political organization.

It should be noted that all the above myth-making techniques appear as different ways of dosing social information in the course of its production and broadcast. Depending on the circumstances of the political process and in accordance with their own needs, society and power implement this dosage.

Thus, the socio-political myth-making appears as necessary component of the political process. At that on the one hand, myth-making increases the efficiency of the socio-political impact, but on the other hand, by distorting the political realities, it represents them as 'required' for the ruling structures and 'desired' for the society at the same time. The history knows many examples of the facts when such distortions mostly lead to realization of the manipulators' goal.

According to Osipov G. V., the main effect of the myth-making process is that while being materialized, it is inevitably accompanied by the consequences of 'the reverse effect', i.e. the results, the possibility of which no one anticipated and wanted (Osipov, 2002, p. 207).

Thus, despite the presence of mostly negative moments, in our view, the socio-political myth, interpreting the existing reality, creates an ideal and corroborates the type of reproduction of social relations, as 'political myths are closely intertwined with some knowledge of the social reality. But more important is their function of the political behavior regulator through the use of emotional and psychological mechanisms. They act as a kind of compensator of the lack of scientific knowledge in the realm of politics. It is well known that science can provide only a partial and subject to correction image of the real world, according to which one can't be absolutely sure of the correctness of his actions. Such confidence is provided by the political myth, which is the intrinsically irrational absolute faith in the ultimate victory and faith in the attainability of the target social goals. That's why every major political movement tries to imbody its goals into a myth, which is taken by people as hope, assigning a specific meaning, excitement and passion to their collective actions' (Osipov, 2002, p. 184).

The logic of the political myth is to transfer certain causality, disputed in the result of the social crisis, into the sphere of mythical images, where a new causality can be found and then moved to the realm of politics. Thus political myth bears an original research logic that operates in the absence of complete basic data.

Thus, recognizing the social and political myth-making as an integral part of the political process, we came to the following conclusions:

- The political myth is based on the archaic myth prototype. It has its own plan of reality - with its logic and plot laws, its own system of symbols and images. But as opposed to the archaic myth, the political myth is formed not only by the emotional experience, but also by the rationally approved semantic core; 
- The political myth, performing a function of restoring the picture of the world, permanently destroyed during a social cataclysm, in some or other way refers to the sense-life reasons, among which the motives of freedom and destiny, the motives of life and death stand apart;

- The positive side of the political myth is seen only in its relation to the cultural and national traditions;

-The political myth simultaneously acts as a tool to manipulate society and the tool for resolution of existential problems, without which it is impossible to proceed to the solution of practical problems.

In general, the awareness of the tangible nature and capabilities of the political myth facilitate the more effective usage of the consciousness of its beneficial capabilities and protection of consciousness from its adverse effect.

\section{References}

Avtonomova, N. S. (1990). Mif: khaos i logos. Zabluzhdayushchiysya razum? (pp. 30-57).

Bart, R. (1989). Mif segodnya // Izbrannye raboty: Semiotika. Poetika (pp. 79-273). M.: Progress.

Bekezhanov, O. K. (1998). Mif zhane onyn kogamdyk sanadagy orny: filos.gyl. kand.avtoref.: 09.00.11 (p. 25).

Gachev, G. D. (1994). Natsionalnyy mif $i$ Kultura // Mif $i$ kultura: chelovek-ne- chelovek: tezisy Konferentsii (p. 79-83).

Hyubner, K. (1996). Istina mifa (p. 328). M.: Respublika.

Kara-Murza, S. G. (2002). Kratkiy kurs manipulyatsii soznaniem (p. 210).

Kassirer, E. (1993). Mif gosudarstva // Fenomen cheloveka: antologia (pp. 112-119). M.: Vysshaya shkola.

Kassirer, E. (1993). Tekhnika politicheskikh mifov. Fenomen cheloveka.

Lebon, G. (1995). Psikhologiya narodov i mass. SPb.: Nauka.

Losev, A. F. (2001). Dialektika mifa (pp. 51-258).

Losev, A. F. (1994). Mif. Chislo. Sushchnost (p. 216). M.: Mysl.

Pivoev, V. M. (1993). Funktsii mifa v culture. Vestnik MGU. Seriya 7. Filosofiya, 3, 37-45.

Polosin, V. S. (1999). Mif. Religiya. Gosudarstvo: issledovanie politicheskoi mifologii (p. 40-94). Ladomir.

Ryazanova, S. V. (2005). Mif i politika: logika vzaimootnoshenya. Materialy Tretey mezhdunarodnoy konferentsii ESPI (p. 256). - Ekaterinburg: Uralskoe otd-e RAN.

Tsuladze, A. (2003). Politicheskaya mifologiya (pp. 56-165).

Zhores, Zh. (1983). Sotsialnaya istoriya frantsuzskoi revolyutsii: v 6, 1, 340.

Kassirer, E. (1998). Opyt o cheloveke (pp. 529-580). Gardarika.

Kasкabasov, S. (1992). Kolybel iskusstva (p. 368). Alma-Ata: Oner.

Kolev, A. N. (2003). Politicheskaya mifologiya (p. 381).

Moiseev, A. G. (1994). Smysl chelovecheskogo bytiya. Sotsialno - politicheskiy zhurnal, 3, 5-6.

Moskovichi, C. (1998). Vek tolp (istoricheskiy traktat po psikhologii mass) (p. 480) - M.: Tsentr psikhologii i psikhoterapii.

Osipov, G. V. (2000). Socialnoe mifotvorchestvo i socialnaya praktika (p. 543). Izd-vo NORMA.

Turyszhanova, R. K. (2003). Mirovozzrencheskie tsennocti lichnosti v usloviyakh tsivilizovannogo razvitiya Respubliki Kazakhstan. Kazakhstanskaya tsivilizatsia v kontekste globalizatsii i poiski putei kulturnoi identifikatsii: materialy mezhdunarodnoy nauchnoy konferentsii (p. 338). Almaty: Kazak univ-ту.

\section{Copyrights}

Copyright for this article is retained by the author(s), with first publication rights granted to the journal.

This is an open-access article distributed under the terms and conditions of the Creative Commons Attribution license (http://creativecommons.org/licenses/by/3.0/). 